\title{
Research on Cultivation of Ability of Writing Compositions in Business Russian
}

\author{
Chen Binbin \\ Zunyi Normal College, Zunyi, Guizhou, China, 563002 \\ hunter2011@foxmail.com
}

Keywords: Writing compositions, Business Russian, cultivation of ability

\begin{abstract}
Business Russian is a kind of Russian language for international trade and international marketing. Therefore, the business Russian has formed its own stylistic features, namely, diction appropriation, accuracy, paying attention to courtesy, clear meaning and simplicity. In view of this, the business Russian writing course should be taught how to reflect these characteristics in business writing. This paper gives the models and process of cultivating business Russian writing ability in order to provide some references for the relevant researchers.
\end{abstract}

\section{Concept of Business Russian}

Business Russian belongs to the category of Applied Linguistics, which is used in the specific business activities of Russian. In a broad sense, business Russian involves all aspects of international business activities, such as: business negotiation, contract signing and performance, international transportation, insurance, logistics, international payment and settlement, commodity inspection and customs, etc. Past of Russian business knowledge is limited. Only pay attention to the connotation of it. We always focus on the basis of proficient in Russian grasp of business Russian certain phrases, sentences and business correspondence writing, ignoring its extension. In the end, it is said that the students have a special purpose of the language knowledge, but did not get the real professional knowledge and ability, and thus cannot meet the needs of the community. For the relationship between the connotation and extension of business Russian, we can conclude that: first of all, the connotation is the basis. Have a solid knowledge of the language and the language of the language is to become good business foreign language skills; second, the connotation of the extension service. The use of foreign languages in the work of business Russian talents in the final analysis is to carry out business activities, to achieve the purpose of business activities. Finally, the connotation and extension of the mutual connection, mutual complement. Only the organic combination of them, can we find a reasonable and effective development mode of business Russian professional language.

\section{Characteristics of Business Russian}

Vocabulary Characteristics. The lexical features of business Russian showed strong professional and frequent use of abbreviations and borrowed words. Because of the knowledge of the business, such as law, economy, trade, finance, insurance, customs, and commodity inspection and so on, there are some common language, legal language, legal language in the contract and agreement. It is also due to business activities to the point, the pursuit of high efficiency. Therefore, Russian business was made of broad and strong words, often using the abbreviations and borrowing foreign words. In addition to a large number of professional terms in Business English, the written language is also common, it is emphasized that the actual objective description, so the use of the word clear and specific, there is no ambiguity of the phenomenon of language. The characteristics of the written language is the formal and accurate, the business of the Russian language in the use of oral expression, because the expression of the colloquial language of the phenomenon, and the language of business Russian. Russian business Russian as used in business activities, often involving the flow of funds or legal responsibility, and will never allow vague, instead some unfamiliar words. 
Grammar Characteristics. The use of passive sentences, the emphasis on passive movements canforeground the action of the bear, and the relevant items as a guest view and regulations, therefore, the frequent use of passive verb phrase and its short tail form. Commercial Russian involves the capital flow and the legal responsibility of the business, must be objective and fair, often use the passive voice to express a fair position, in order to accurately describe the facts. We often use the imperative sentences, simple and authentic language, not dragging its feet polite circumlocution.

Sentence Characteristics. In the long-term international business communication, people formed a series of concise and practical business professional typical apply statements and relatively fixed format specification. Take the economic contract as an example, its structure generally includes: title, contract number, place and date, the name of the parties, the subject clause; the end of the contract, the legal address of the parties, and the signature of both parties. In short, business Russian based on the basic vocabulary, grammar and syntax structure, but also has its own unique language phenomenon and performance. Business Russian content is meticulous, thoughtful, complex structure, meaning complete due to the interests of parties or several aspects, business contracts, documents or a treaty to define, terms and content must be accurate. In order to achieve accurate and correct, without any differences, with Russian language, writing these documents, contracts, in addition to the use of the word, but also often use a lot of clauses, phrases used to modify or limit its content, so the sentence structure is complex.

\section{Cultivation Models of Ability of Writing Compositions in Business Russian}

Business Russian generally uses the traditional teaching model or the project teaching model. In fact, the combination of the two will have a good teaching effect. The teaching mode of the traditional foreign language writing is to explain the writing of the title, to explain the key words, to sum up the typical sentence patterns, such as the sample, such as a series of forms of teaching. The whole teaching process covers the knowledge system of the system, and the goal is clear. The students can memorize the vocabulary and master the sentence patterns by the teacher's explanation. But it is not difficult to find out the articles written by the students. Writing itself is a reflection of the form of human thinking, everyone's way of thinking are not exactly. All the students write the same article. This is not the purpose of writing teaching. In the traditional teaching mode, students are in a passive receiving knowledge. The students' learning initiative and autonomy are difficult to be mobilized. This knowledge system is systematically analyzed from another aspect, which can restrain the students' ability of independent thinking. Students do not to think how to write some articles, most of the students take the nave in individual lexical substitution way to complete the task of writing. The project teaching is the main line of the real work flow. According to the main line to set up a number of tasks, each task requires students to master a specific business style writing method. In the teaching of the project, the students have some ability to ask for their own requirements, the students learn from the target more clearly. The students can follow their own way of thinking and the ability to analyze and deal with the problem when the teacher is assigned. Some of the style in business Russian writing has a certain standard, so it is not meant to allow students fully and completely. The teachers should communicate with the students in the process of each task. After the completion of the task, teachers should correct the errors in the students' papers.

\section{Cultivation Process of Ability of Writing Compositions in Business Russian}

Business Russian writing includes two aspects: business letters and business contracts written in Russian. In all trade between China and Russia in the process, the Russian business correspondence is the most common way to solve problems taken, the writing of Russian business contract is bilateral trade agreement of the final identification: in the process of the training of the ability of writing, teachers should not only using the traditional teaching pattern, make clear knowledge system, should be appropriate to the introduction of the project of teaching, develop more suitable for business writing in Russian teaching mode, cultivation of Russian writing ability of students in 
business to get better. Combining the traditional teaching method and the teaching method, the teaching process of business Russian writing course is divided into the following steps:

Set the Goal. The teachers set the goal of the business Russian writing courses. In the early stage, the whole course is analyzed, and a complete business process is set up. The main line of the course can be set to the seller and the buyer to sign a trade contract. The project includes the preparation period, the period and the complete period of the trade cooperation. The type of product is available on its own, but in principle, students are not allowed to change the type of product in the middle of the day. All the styles of business Russian writing are condensed into a specific practical work. At the same time, it can make students realize the importance of knowledge in the course of business activities, and make students more achievements, stimulate students' learning interest. In this part, the overall direction of the curriculum is set by the teachers, and the project can not deviate from the overall objectives of the course, and be able to meet the requirements of the curriculum knowledge and the ability of the target.

Decompose the Project. The project is decomposed into a number of tasks by students through the discussion according to the basic process of trade. Students in the form of classroom discussion, the teacher set the project to break down, through a number of tasks to achieve the final completion of the project, in the course of the project, the students through self-learning clear in when, what circumstances, the need to book on what style. At this time, the introduction of a variety of business Russian language writing style of the application occasions, so that the knowledge of the embedded more reasonable, the combination of theory and practice.

Express the Task. The teacher issues the task, and the students write thecom positions Assigned tasks by the teacher to complete, after the students received the task, the first idea of their overall program, and communicate with the teachers, after the program was passed, the students began to collect the required vocabulary, forming a written material. If the students plan has not been adopted, the teacher needs to point out the inadequacies of the program, the students to improve the program. In this process, students are the main body, students through the design of writing program, the final written, simulation of the real work process, teachers play a guiding role in the link.

Summarize the Experience. Teachers and students separately summarize the experiences. In the process of the task, the teacher and the student's role is different, undertake the task is different, so the summary of the angle is also different. According to the students' final papers, the teacher has some common problems in writing, in order to make the students better understand and avoid the problem again. And students need to sum up the tasks in the process of their own have encountered problems. These problems may have been solved, not reflected in the article, but these problems are the personality of each student may encounter, if there is no communication between students and summary, these personality problems may occur in other students. Therefore, after the completion of the work experience, the experience of teachers and students will have some links.

Study the Case. Students find the problems through the typical case analysis. In order to avoid the students to the case of the form is too dependent on the case. The case will be displayed after each task. Premature demonstration of the case, it is bound to cultivate students' ability to think independently and the ability to write a negative impact. Through the case of the show, we hope that the students will work with the case to compare, find their own can improve the space, improve the shortage.

\section{Conclusion}

Business Russian writing course requires two aspects of professional knowledge, which are international business and Russian writing. The stylistics the different style of writing can promote the teaching of business writing in Russian. Based on the characteristics of the business language, this paper gives the models and process of the training of the ability of the business. To cultivate students' ability of business writing, to stimulate students' interest, and to improve the teaching method is the method. To say goodbye to the past, teachers only pay attention to knowledge teaching, students can only passively accept the mode, reasonable arrangement of classroom 
teaching, the project throughout the whole teaching process. Only in this way can help students have high business Russian writing skills.

\section{References}

[1] J.Y. Liu, On the Cultivation of the Ability to Write Compositions in Russian, Journal of Harbin University, 6(2002)86-87.

[2] X.F. Meng, H. Zhang, Schema Theory and College Russian Writing Teaching, Journal of Nanchang College of Education, 25(2010)151-152.

[3] P. Ge, How to Instruct Russian Writing before General Russian Test, Journal of Jilin Commercial College, 1(2006)24-25

[4] H.L. Zhang, My Analysison TrainingWriting AbilityinRussianClassTeaching, Journal of Qiqihar University(Phi \& SocSci), 9(2011)97-98.

[5] Y.M. Xu, On Reform of Business Russian Teaching in Universities, Journal of Jixi University, 1(2014)96-97. 